Prepared for the U.S. Department of Energy

under Contract DE-AC05-76RL01830

\title{
Enhanced Densification of SDC Barrier Layers
}

\author{
J.S. Hardy \\ J.W. Templeton \\ Z. Lu \\ J.W. Stevenson \\ Pacific Northwest National Laboratory, Richland, WA
}

September 2011
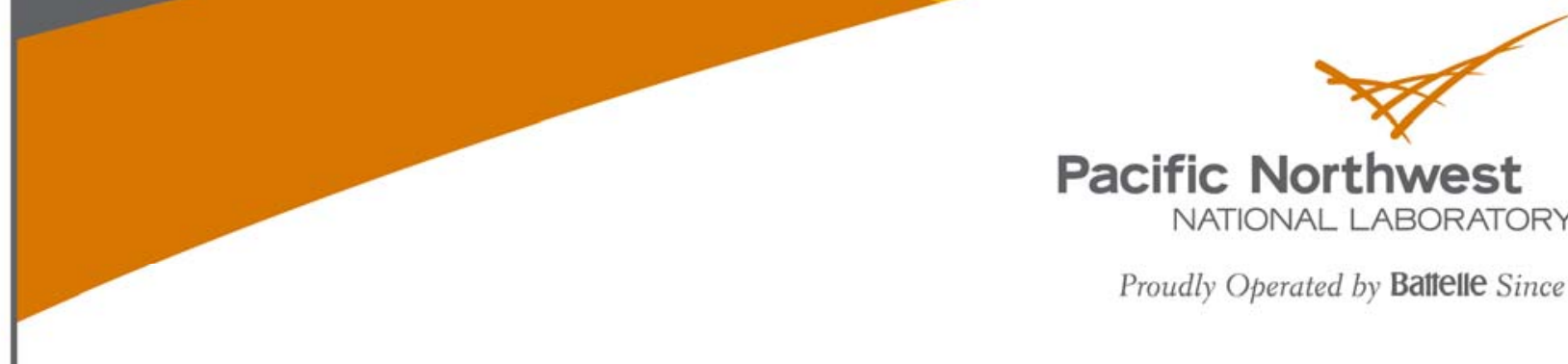

Pacific Northwest

NATIONAL LABORATORY

Proudly Operated by Battelle Since 1965 


\title{
DISCLAIMER
}

This report was prepared as an account of work sponsored by an agency of the United States Government. Neither the United States Government nor any agency thereof, nor Battelle Memorial Institute, nor any of their employees, makes any warranty, express or implied, or assumes any legal liability or responsibility for the accuracy, completeness, or usefulness of any information, apparatus, product, or process disclosed, or represents that its use would not infringe privately owned rights. Reference herein to any specific commercial product, process, or service by trade name, trademark, manufacturer, or otherwise does not necessarily constitute or imply its endorsement, recommendation, or favoring by the United States Government or any agency thereof, or Battelle Memorial Institute. The views and opinions of authors expressed herein do not necessarily state or reflect those of the United States Government or any agency thereof.

\author{
PACIFIC NORTHWEST NATIONAL LABORATORY \\ operated by \\ BATTELLE \\ for the \\ UNITED STATES DEPARTMENT OF ENERGY \\ under Contract DE-AC05-76RL01830
}

Printed in the United States of America
Available to DOE and DOE contractors from the Office of Scientific and Technical Information,
P.O. Box 62, Oak Ridge, TN 37831-0062;
ph: (865) 576-8401
fax: $(865)$ 576-5728
email: reports@adonis.osti.gov

\begin{abstract}
Available to the public from the National Technical Information Service, U.S. Department of Commerce, 5285 Port Royal Rd., Springfield, VA 22161 ph: (800) 553-6847 fax: $(703) 605-6900$ email: orders@ntis.fedworld.gov online ordering: http://www.ntis.gov/ordering.htm
\end{abstract}

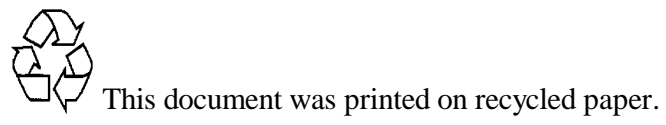




\title{
Enhanced Densification of SDC Barrier Layers
}

\author{
JS Hardy \\ $\mathrm{Z} \mathrm{Lu}$ \\ JW Templeton \\ JW Stevenson
}

September 2011

Prepared for the U.S. Department of Energy

under Contract DE-AC05-76RL01830

Pacific Northwest National Laboratory

Richland, Washington 99352 


\section{Introduction}

A samaria-doped ceria (SDC) barrier layer separates the lanthanum strontium cobalt ferrite (LSCF) cathode from the yttria-stabilized zirconia (YSZ) electrolyte in a solid oxide fuel cell (SOFC) to prevent the formation of electrically resistive interfacial $\mathrm{SrZrO}_{3}$ layers that arise from the reaction of $\mathrm{Sr}$ from the LSCF with $\mathrm{Zr}$ from the YSZ. However, the sintering temperature of this SDC layer must be limited to $\sim 1200^{\circ} \mathrm{C}$ to avoid extensive interdiffusion between SDC and $\mathrm{YSZ}$ to form a resistive $\mathrm{CeO}_{2}-\mathrm{ZrO}_{2}$ solid solution. Therefore, the conventional SDC layer is often porous and therefore not as impervious to Srdiffusion as would be desired. In the pursuit of improved SOFC performance, efforts have been directed toward increasing the density of the SDC barrier layer without increasing the sintering temperature.

\section{Dense SDC Barrier Layer Prototype}

Figure 1 compares SEM micrographs of a conventional screen printed SDC barrier layer to a pulsed laser deposited (PLD) SDC barrier layer. The PLD SDC barrier layers used in this study were prepared by Alex Ignatiev and Naijuan Wu at the University of Houston. Figure 1a, it can be seen that the screen printed layer is porous. The PLD SDC layer in Figure 1b, on the other hand, is a prototype of the ideally dense SDC barrier layer pursued in this study. Figure 2 compares the electrochemical performance of a cell with the dense PLD SDC to a cell that was similar in all aspects except that it had a conventional screen printed SDC barrier layer. At $0.8 \mathrm{~V}$, the cell with the dense SDC layer generated over $1.1 \mathrm{~W} / \mathrm{cm}^{2}$ while the cell with the screen printed layer generated less than $0.7 \mathrm{~W} / \mathrm{cm}^{2}$. The ohmic and polarization resistances extracted from the impedance spectroscopy data through fitting to an equivalent circuit model are presented in Table 1. While the polarization resistances of the two cells were quite similar at each temperature, the ohmic resistances were significantly lower in the cell with the PLD SDC. Figure 3a plots the total ohmic resistances of the cells as a function of temperature together with the ohmic contribution of the YSZ electrolyte. In Figure 3b, it can be seen that after the ohmic contribution of the YSZ has been subtracted, there is still a significant ohmic resistance of the other components in the cells. However, the improved density of the PLD SDC has greatly reduced this additional ohmic resistance. This is largely due to the increased effectiveness of the dense PLD SDC as a barrier to Sr-diffusion. In Figure 4, it can be seen that $\mathrm{SrZrO}_{3}$ formation at the SDC/YSZ interface in cells with conventional SDC layers increased with the temperature at which the LSCF cathode was sintered, until a thick layer was present after $1200^{\circ} \mathrm{C}$ cathode sintering. However, in Figure 5, after sintering the LSCF cathode on a dense PLD SDC layer at $1200^{\circ} \mathrm{C}$, no $\mathrm{SrZrO}_{3}$ layer was visible. Unfortunately, PLD is an expensive and time consuming process that is not fit for large-scale, high-volume SOFC production, thus other, more cost effective means of enhancing the density of the SDC layer were investigated.

\section{Enhancing SDC Barrier Layer Density}

Decreasing the average particle size. Various approaches to improving densification of the SDC layer were explored. Dilatometry results of powder compacts containing mixtures of various ratios of nano- to submicron-sized powders are shown in Figure 6. It can be seen that by increasing the ratio of nano-sized powders, the sinterability improved. However, in practice, when the powder mixtures were incorporated into a paste, screen printed onto the SOFC bilayers, and sintered at $1200^{\circ} \mathrm{C}$ for 2 hours, they exhibited severe cracking as shown in the micrographs in Figure 7.

Sintering aids and optimized ink formulation. The dilatometry results in Figure 8 illustrate the effect on sinterability of doping the SDC with $2 \mathrm{~mol} \%$ of various sintering aids. It can be seen that $\mathrm{Cu}$ was the most effective additive for improving sinterability. Therefore, the effects of various $\mathrm{Cu}$ doping levels were examined, as shown in Figure 9. The sintering shrinkage did not exhibit a strong dependency on $\mathrm{Cu}$ concentration. Upon determining that $\mathrm{Cu}$-doping enhanced the sintering of SDC without the extensive cracking problem that was seen when the nano-sized powder was introduced, a parametric study was undertaken to examine the effects of the solids loading and binder system used when making the screen print ink. It was determined that the highest densities were obtained by using $2 \mathrm{~mol} \% \mathrm{Cu}$-doped SDC at a 
level of $70 \%$ solids loading in Ferro B-75717 binder. A micrograph of the resulting SDC layer after sintering at $1200^{\circ} \mathrm{C}$ for 2 hours is shown in Figure 10.

\section{Electrochemical Testing and X-ray Diffraction (XRD)}

Unlike the cells with PLD SDC, repeated electrochemical tests of cells with SDC layers made using the optimized ink formulation described above showed no improvement in performance over cells with conventional SDC layers. To understand why this may be the case, powders composed of YSZ and various SDC formulations, including undoped, $2 \mathrm{~mol} \% \mathrm{Co}$-doped, and $2 \mathrm{~mol} \% \mathrm{Cu}$-doped SDC, were mixed together. XRD was performed on each powder mixture before heat treatment, after firing at $1000^{\circ} \mathrm{C}$ for $2 \mathrm{~h}$, and after firing at the typical SDC barrier layer sintering condition of $1200^{\circ} \mathrm{C}$ for $2 \mathrm{~h}$. The results are shown in Figures $11-13$. The propensity for solid solution formation increased with the sinterability of the SDC composition that was measured by dilatometry (see Figure 8). This is most evident when the XRD scans taken after $1000^{\circ} \mathrm{C}$ sintering (in red in each of the figures) are compared. In Figure 11, XRD of the mixture containing undoped SDC determined that the major peak for SDC at $\sim 28.6^{\circ}$ and the major peak for $\mathrm{YSZ}$ at $\sim 30.2^{\circ}$ are largely unchanged after $1000^{\circ} \mathrm{C}$ sintering. Then, in Figure 12, the mixture containing Co-doped SDC exhibits a small peak that has begun to form at $\sim 29.6^{\circ}$ between the two original peaks after $1000^{\circ} \mathrm{C}$ sintering, indicating the beginnings of solid solution formation. Additionally, the two original peaks have decreased in intensity and the YSZ peak has shifted $\sim 0.1^{\circ}$ toward the SDC. Finally, in Figure 13 showing the mixture containing Cu-doped SDC, the original peaks have largely disappeared and a fully formed solid solution peak is present at $\sim 29.6^{\circ}$ after $1000^{\circ} \mathrm{C}$ sintering. There is no sign of the YSZ peak and the only remnant of the SDC peak is a small shoulder on the solid solution peak at around $\sim 29^{\circ}$.

\section{Conclusions}

The density of the SDC barrier layer can be greatly increased through small amounts of Cu-doping of the SDC powder together with increased solids loading and use of an appropriate binder system in the screen print ink. However, the resulting performance of cells with these barrier layers did not exhibit the expected increase in accordance with that achieved with the prototypical PLD SDC layer. It was determined by XRD that increased sinterability of the SDC also results in increased interdiffusivity between the SDC and YSZ, resulting in formation of a highly resistive solid solution.

\section{Acknowledgements}

The work described in this report was funded through the Solid-State Energy Conversion Alliance (SECA) Core Technology Program by the US Department of Energy's National Energy Technology Laboratory (NETL). Pacific Northwest National Laboratory is operated by Battelle for the U.S. Department of Energy under Contract DE-AC06-76RL01830.

Table 1: Comparison of the resistances determined from equivalent circuit modeling of impedance spectroscopy performed on cells with PLD and screen printed SDC layers.

\begin{tabular}{|c|cc|cc|}
\hline Temperature $\left({ }^{\circ} \mathrm{C}\right)$ & \multicolumn{2}{|c|}{ Laser-deposited SDC $\left(\mathrm{W} . \mathrm{cm}^{2}\right)$} & \multicolumn{2}{|c|}{ Screen-printed SDC $\left(\mathrm{W} . \mathrm{cm}^{2}\right)$} \\
\cline { 2 - 5 } & $\mathrm{R}_{\Omega}$ & $\mathrm{R}_{\mathrm{p}}$ & $\mathrm{R}_{\Omega}$ & $\mathrm{R}_{\mathrm{p}}$ \\
\hline 750 & 0.08 & 0.55 & 0.16 & 0.51 \\
700 & 0.13 & 0.67 & 0.22 & 0.68 \\
650 & 0.17 & 1.18 & 0.32 & 1.16 \\
600 & 0.27 & 2.13 & 0.55 & 2.45 \\
\hline
\end{tabular}



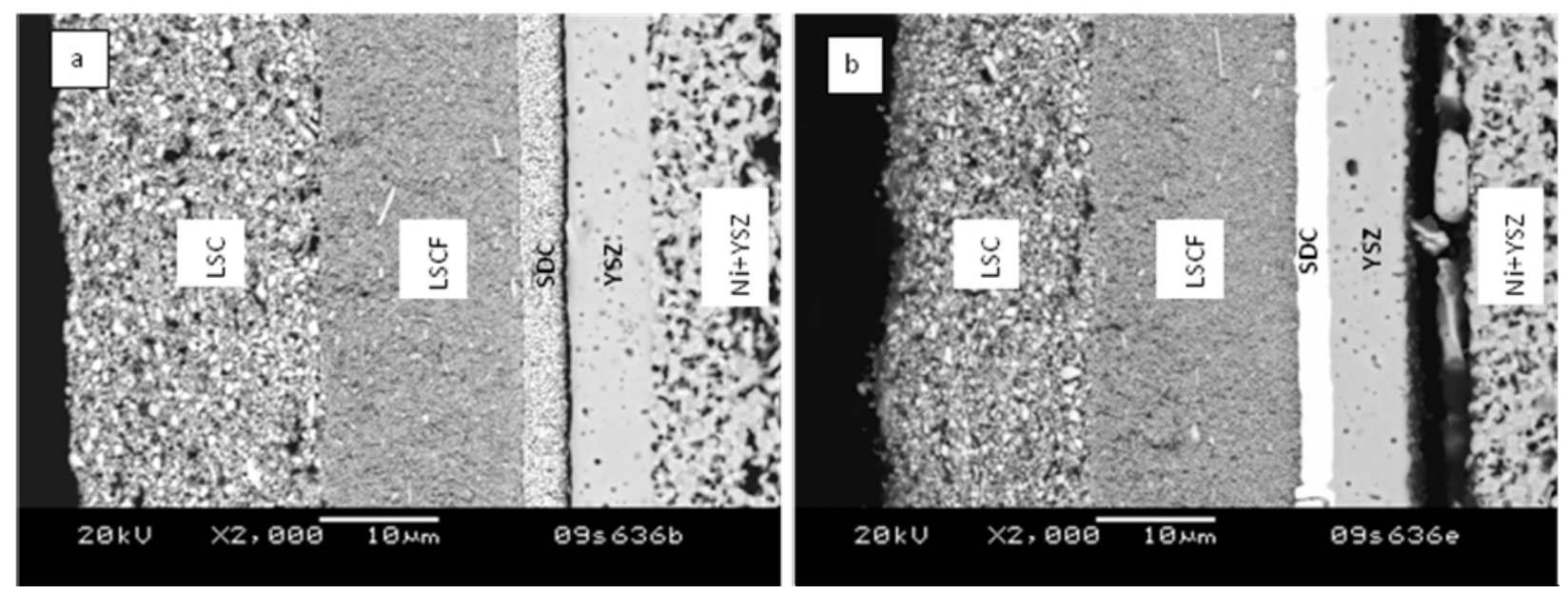

Figure 1: SEM micrographs of cross-sections of fuel cells with (a) screen-printed and (b) laser-deposited SDC interlayers.

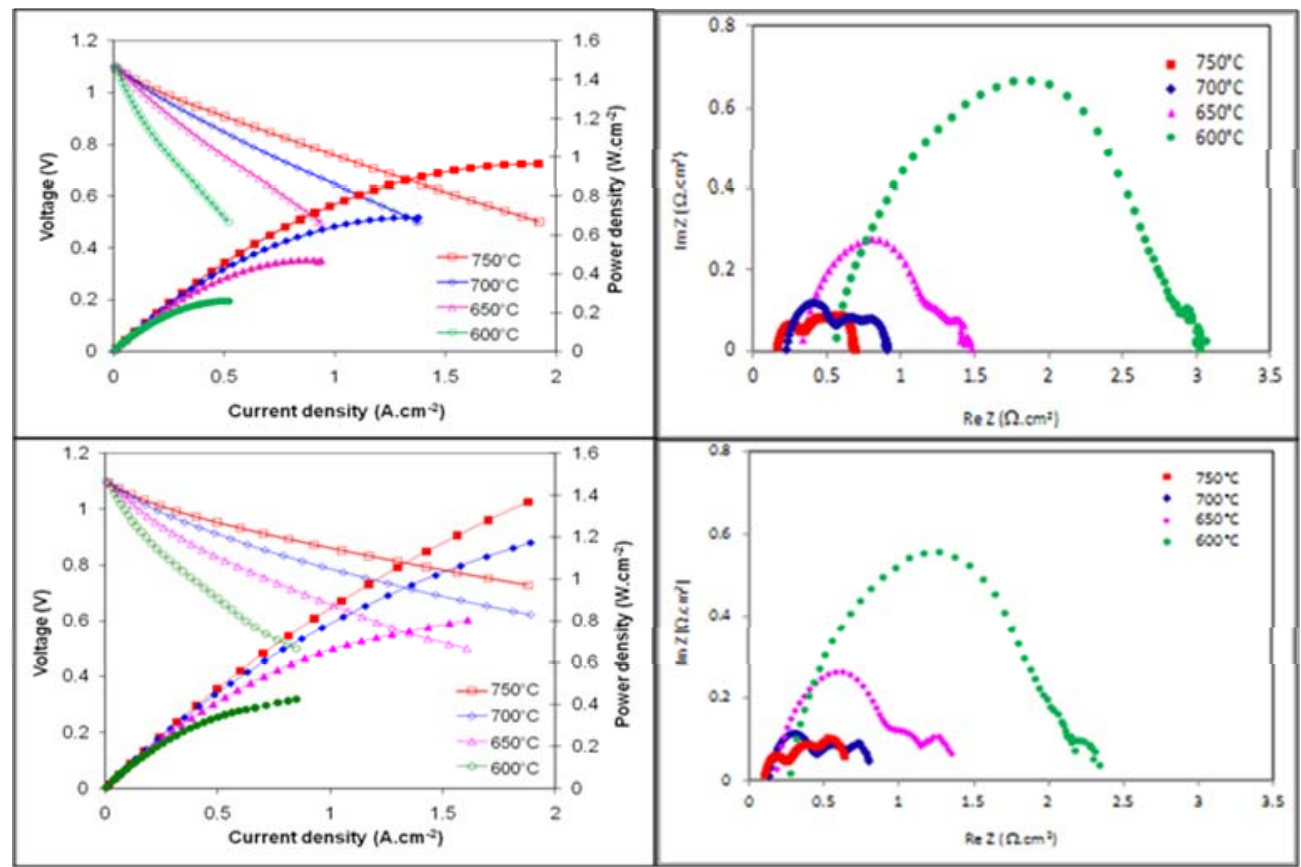

Screen-printed

Laser deposited

Figure 2: Comparison of the I-V curves and impedance spectroscopy of cells with screenprinted (top) and PLD (bottom) SDC barrier layers. 


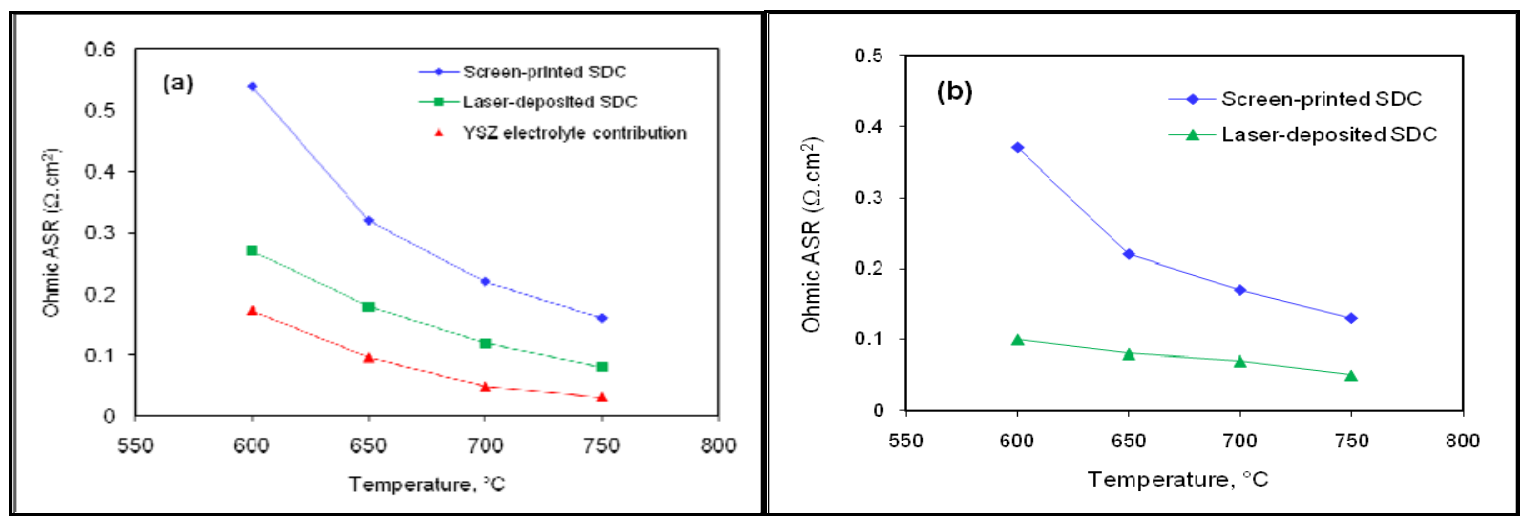

Figure 3: Ohmic resistances of fuel cells with screen-printed and laser-deposited SDC interlayers (a) before and (b) after deduction of the contribution from the YSZ electrolyte.
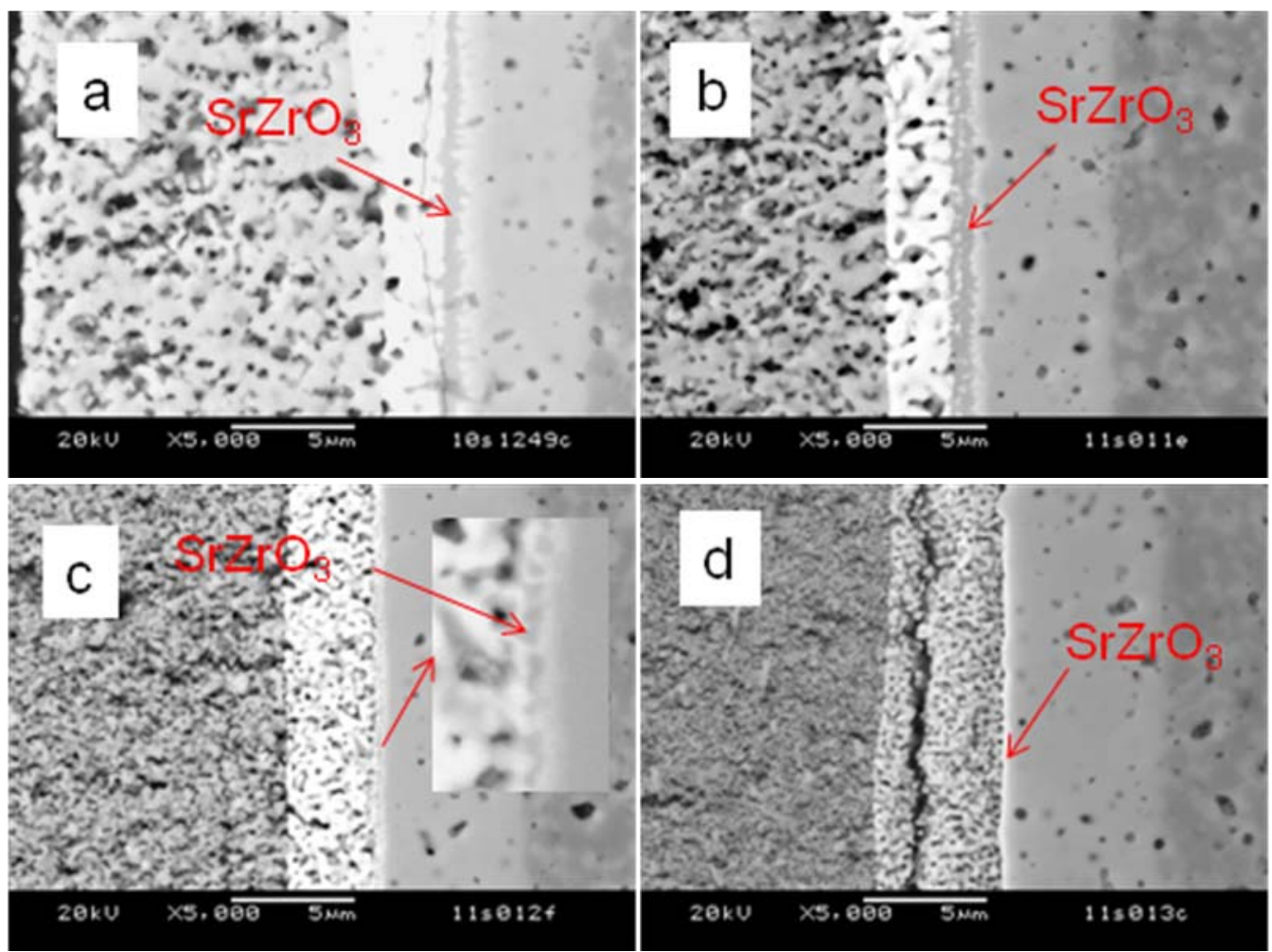

Figure 4: Cross-sectional SEM images of fuel cells with cathodes sintered at (a) $1200^{\circ} \mathrm{C}$, (b) $1150^{\circ} \mathrm{C}$, (c) $1100^{\circ} \mathrm{C}$, and (d) $1050^{\circ} \mathrm{C}$ for $2 \mathrm{~h}$ on conventional screen printed SDC barrier layers. 


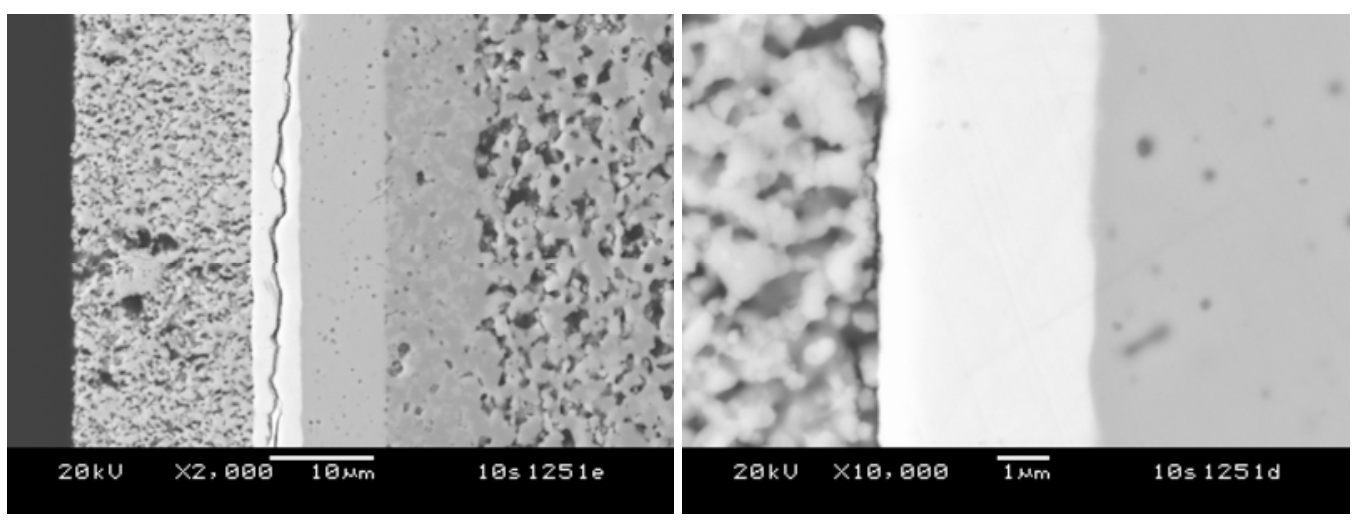

Figure 5: Cross-sectional SEM images of fuel cells with laser-deposited SDC interlayer and LSCF cathodes sintered at $1200^{\circ} \mathrm{C}$ for $2 \mathrm{~h}$. No SrZrO3 formation is observed.

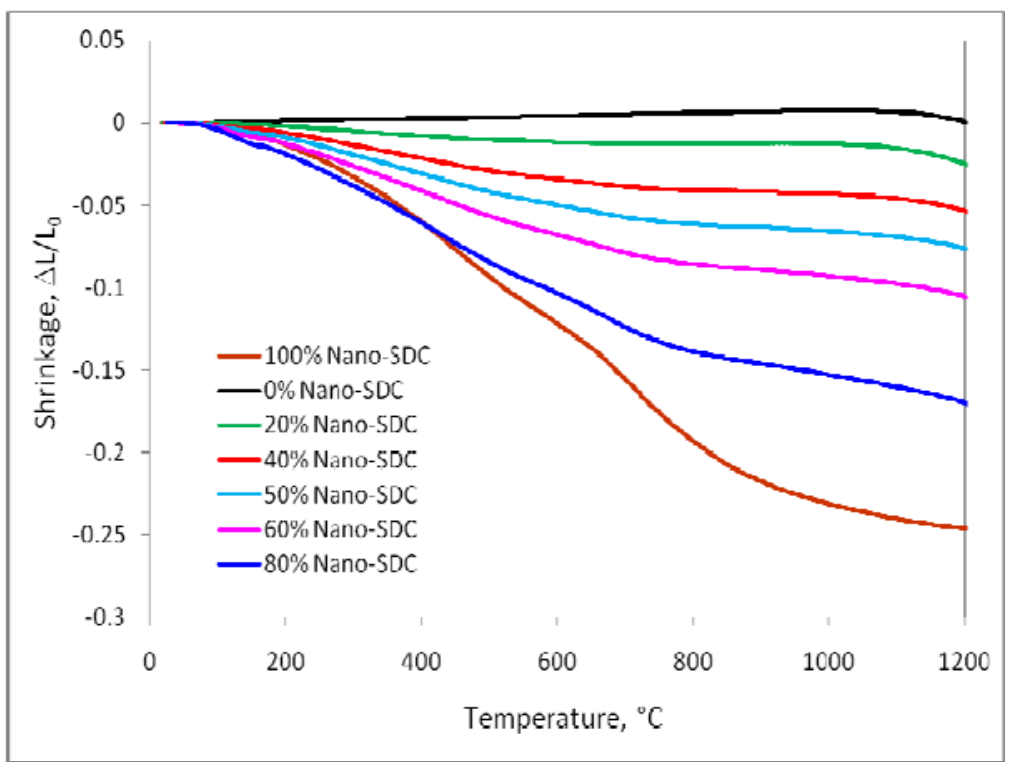

Figure 6: Dilatometric results of compact SDC powders with various ratios of nano-sized powder to submicron-sized powder. 


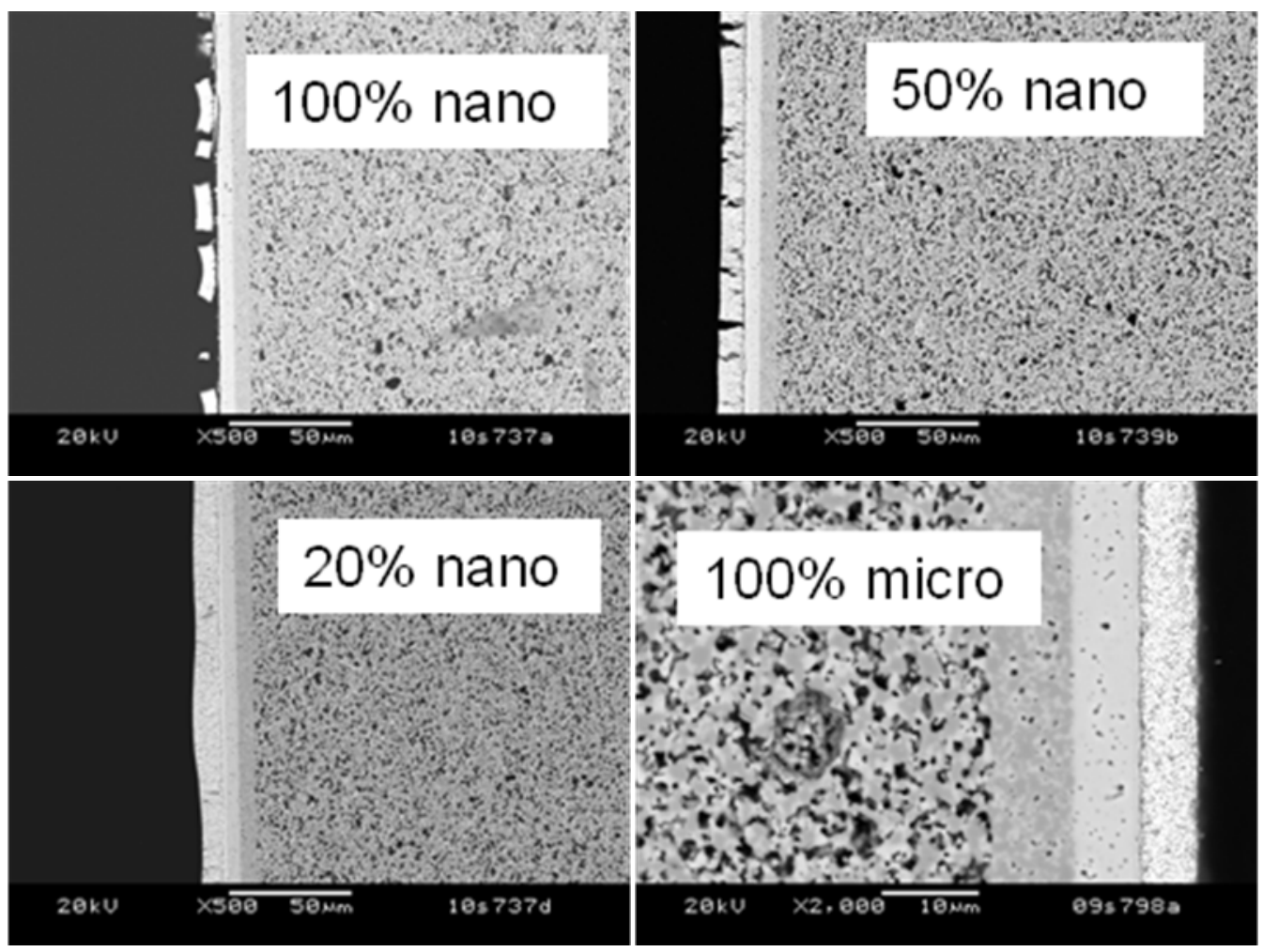

Figure 7: SEM images of SDC interlayers sintered at $1200 \mathrm{C}$ for $2 \mathrm{~h}$ with various ratios of nano-sized powder to micro-sized powder.

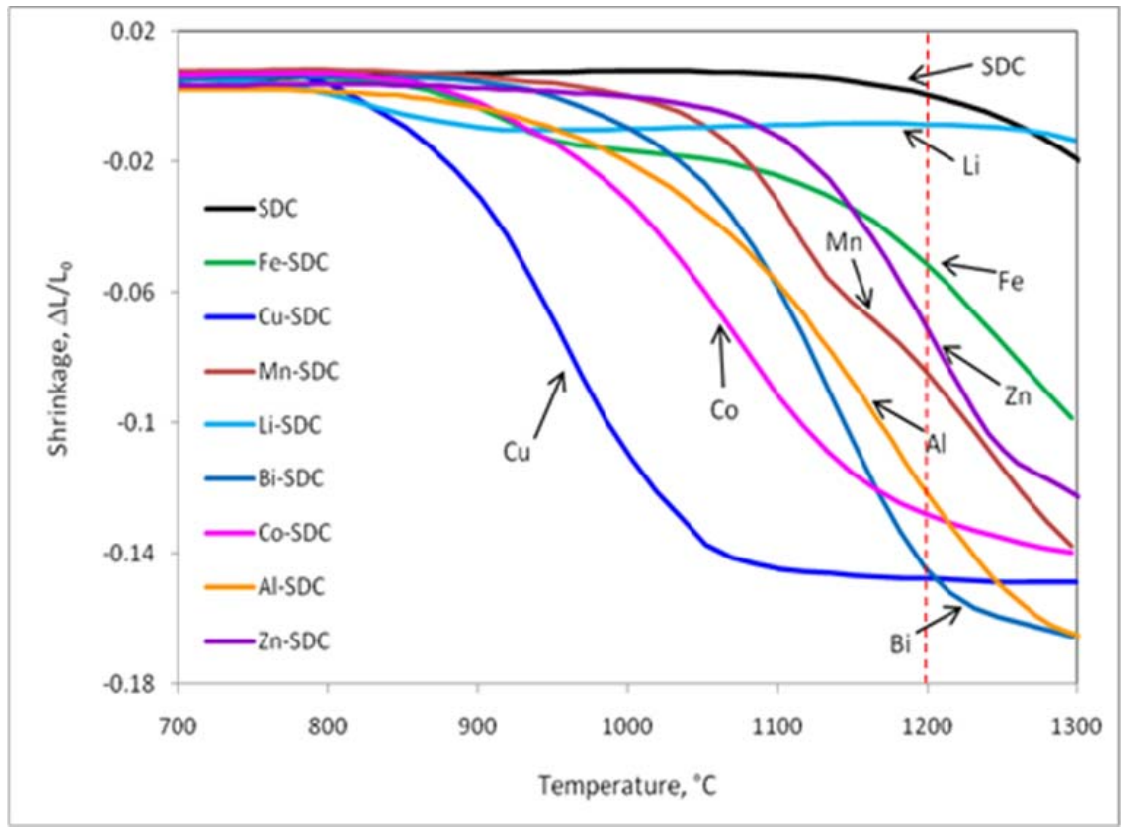

Figure 8: Dilatometric results of the effects of $2 \mathrm{~mol} \%$ of various sintering aids in SDC on sinterability. 


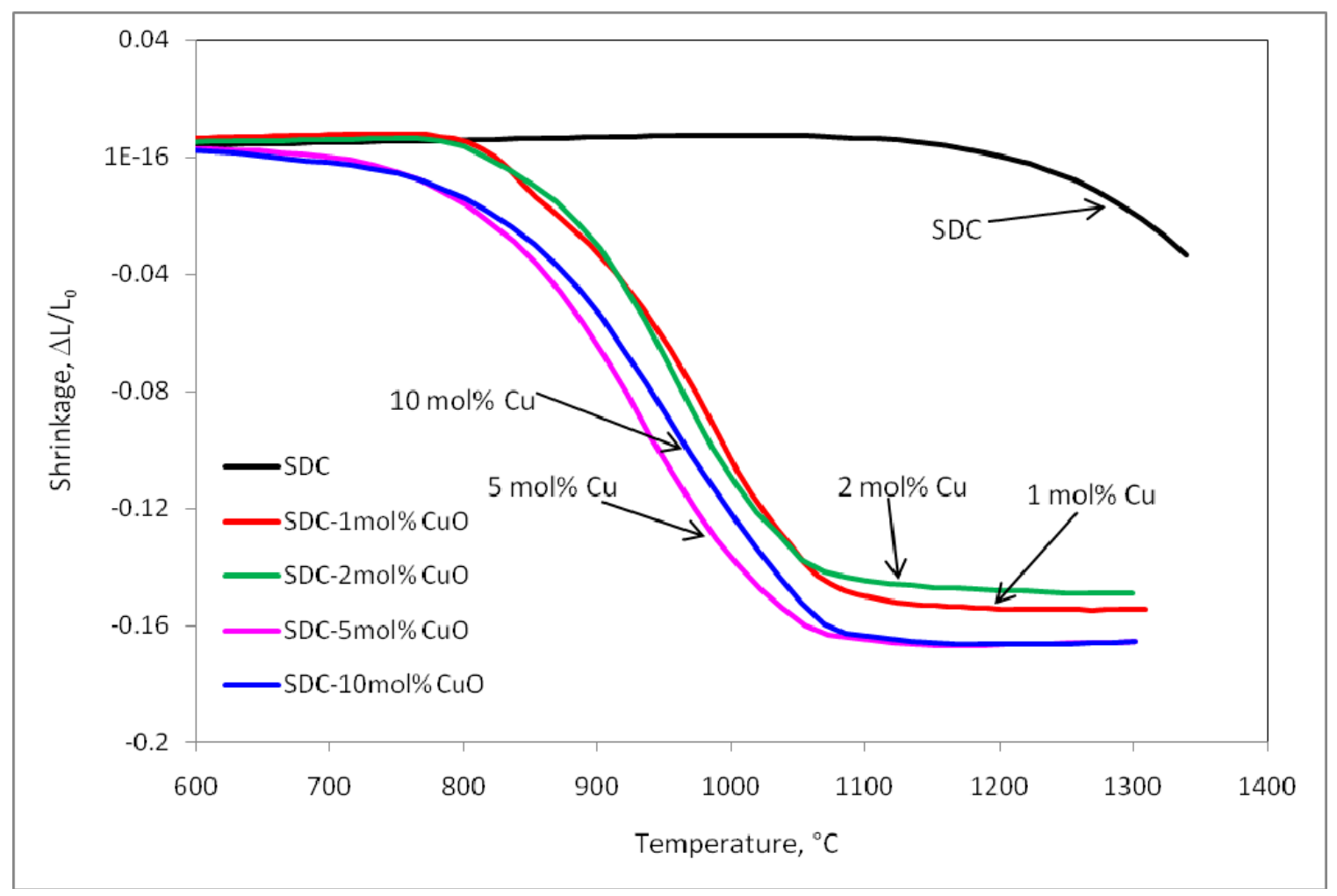

Figure 9: Dilatometric results of SDC powders with various concentrations of $\mathrm{Cu}$-doping.

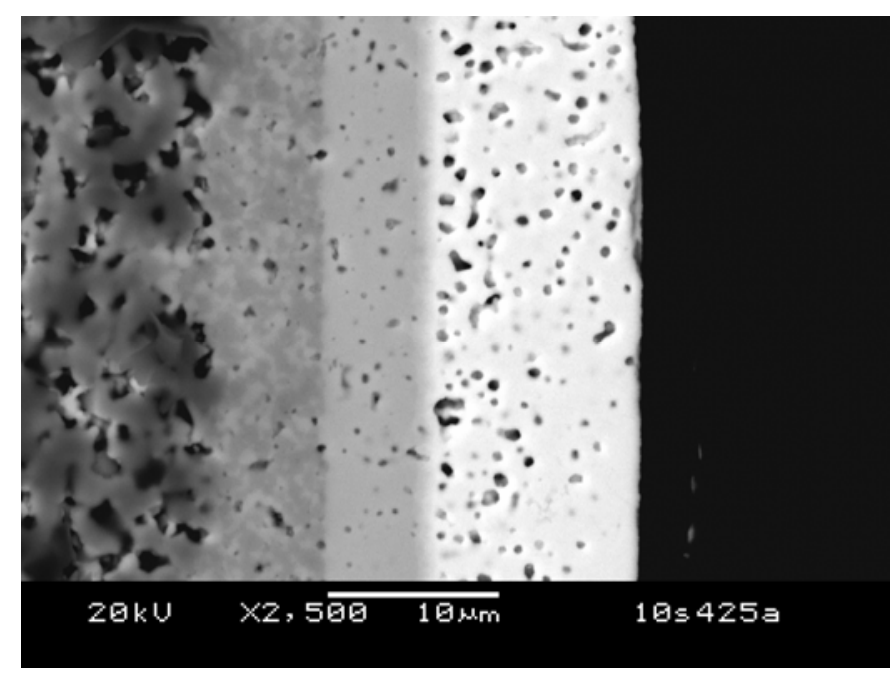

Figure 10: SEM micrograph of a cell with the SDC layer made from screen print ink with $2 \mathrm{~mol} \% \mathrm{Cu}-$ doped SDC in Ferro B-75717 binder at 70\% solids loading. 


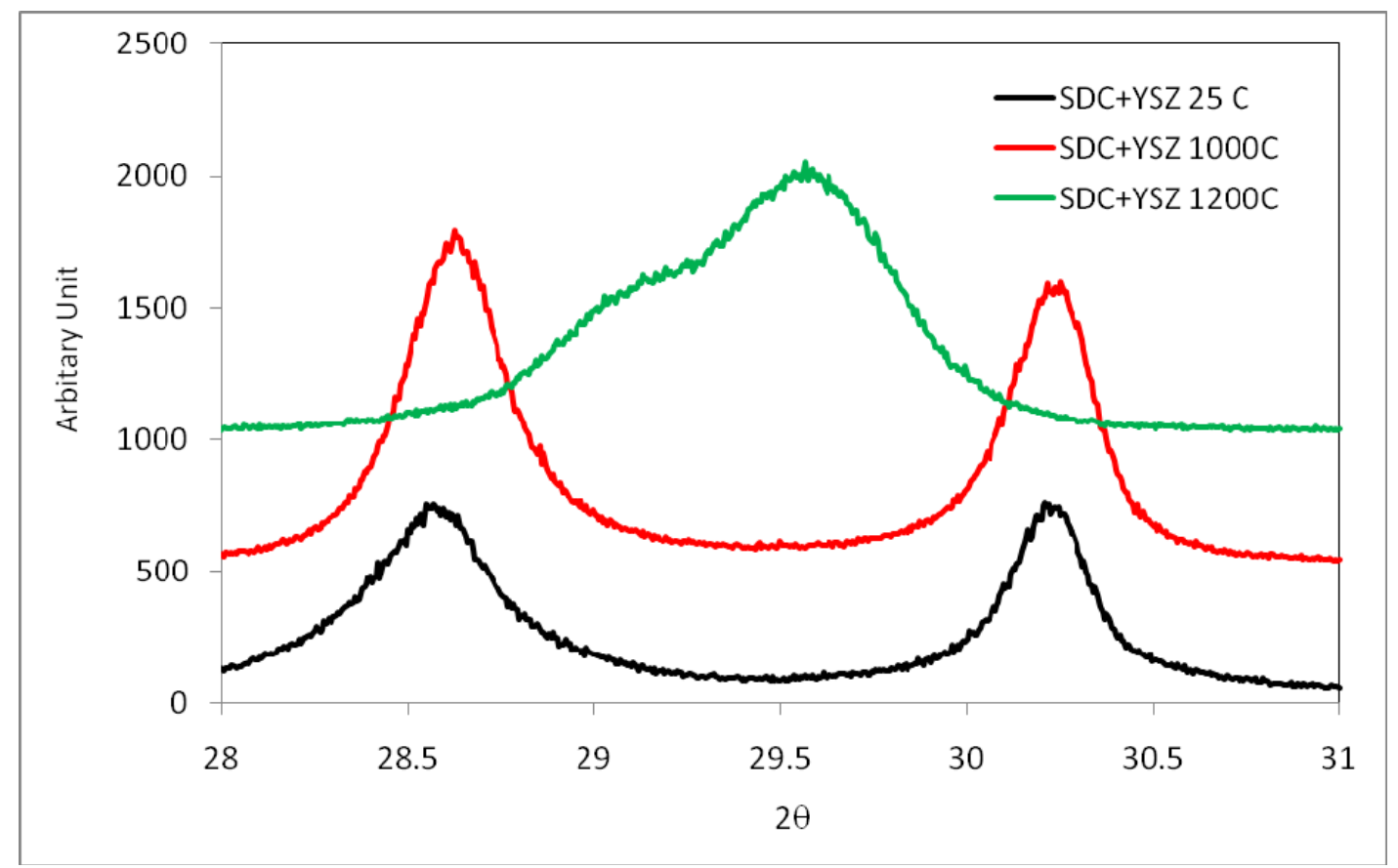

Figure 11: XRD diffraction patterns of undoped SDC+YSZ composite powder sintered at different temperatures.

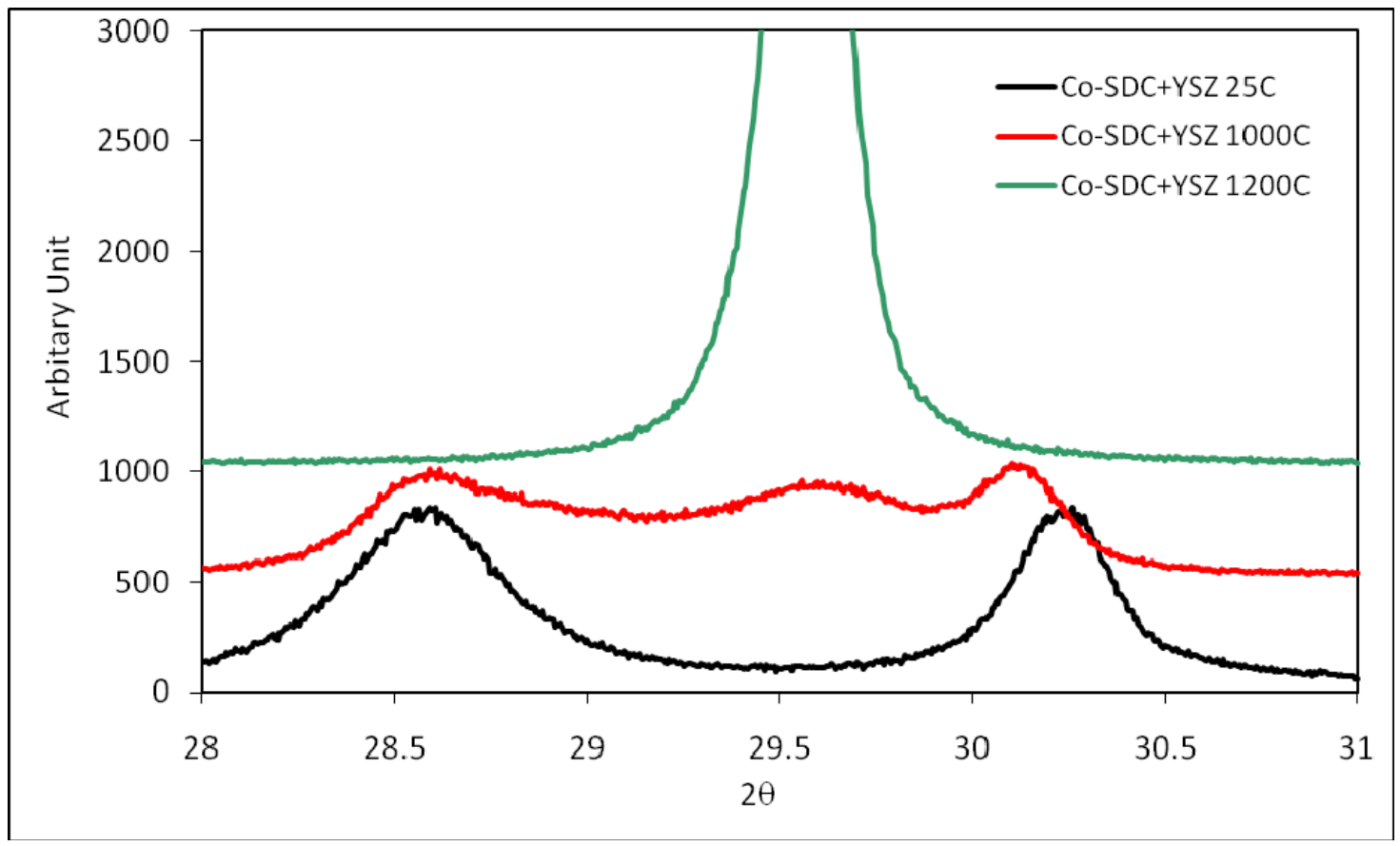

Figure 12: XRD diffraction patterns of Co-doped SDC+YSZ composite powder sintered at different temperatures. 


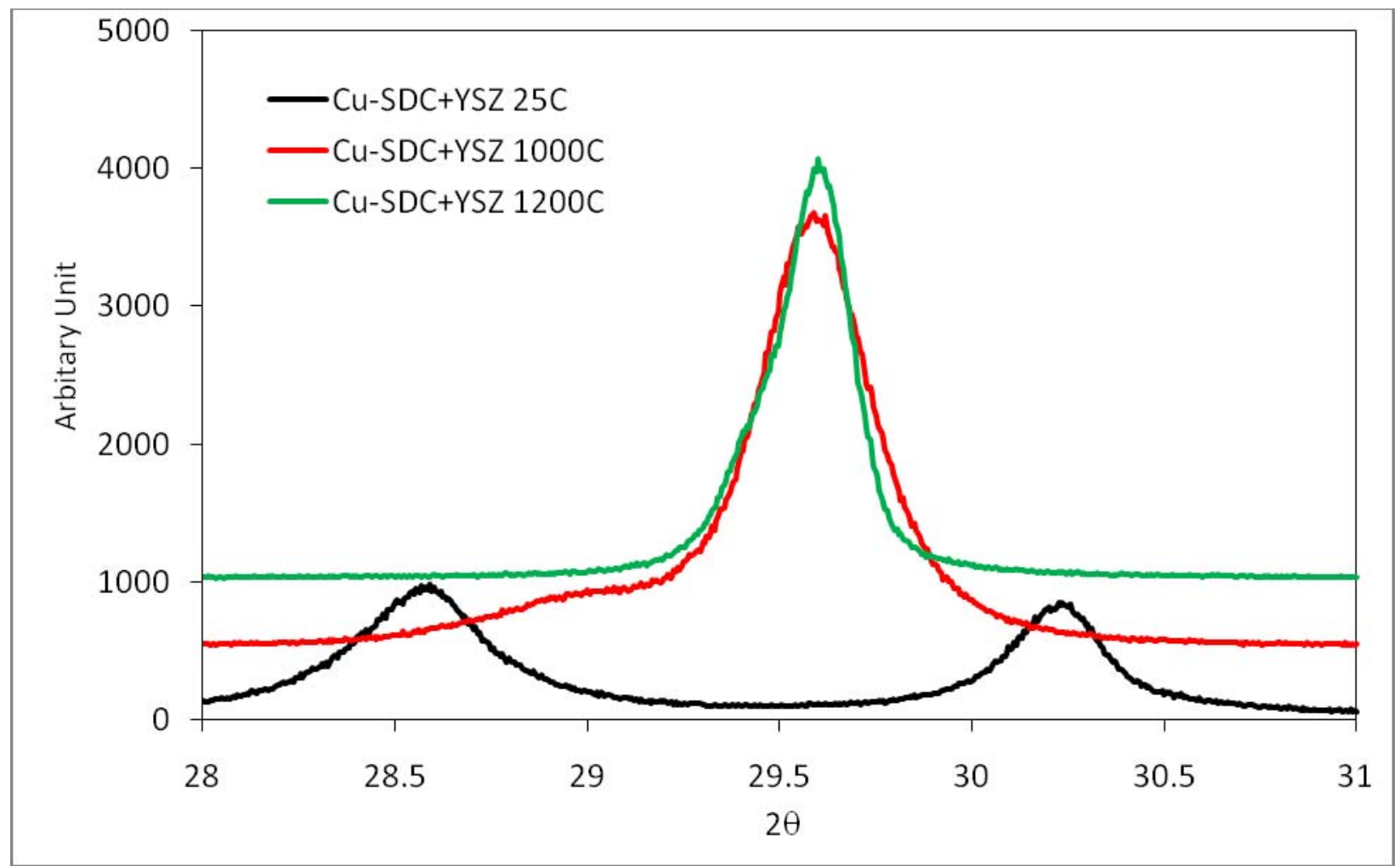

Figure 13: XRD diffraction patterns of $\mathrm{Cu}$-doped SDC+YSZ composite powder sintered at different temperatures. 